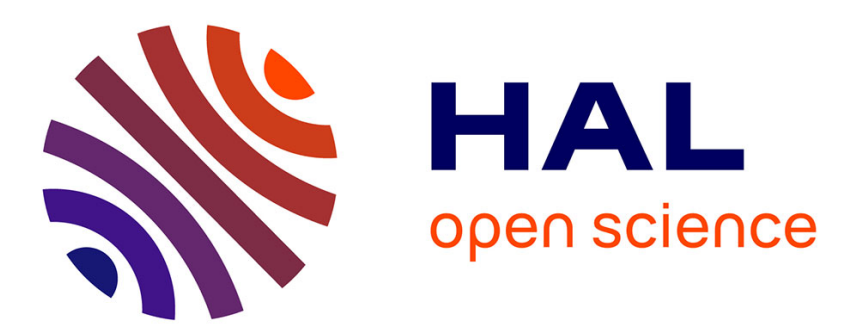

\title{
First identification of a Cathaysian continental fragment beneath the Gagua Ridge, Philippine Sea, and its tectonic implications
}

Shengping Qian, Xiaozhi Zhang, Jonny Wu, Serge Lallemand, Alexander R.L. Nichols, Chiyue Huang, Daniel P Miggins, Huaiyang Zhou

\section{To cite this version:}

Shengping Qian, Xiaozhi Zhang, Jonny Wu, Serge Lallemand, Alexander R.L. Nichols, et al.. First identification of a Cathaysian continental fragment beneath the Gagua Ridge, Philippine Sea, and its tectonic implications. Geology, 2021, 49, 10.1130/G48956.1 . hal-03362061

\section{HAL Id: hal-03362061 https://hal.science/hal-03362061}

Submitted on 8 Oct 2021

HAL is a multi-disciplinary open access archive for the deposit and dissemination of scientific research documents, whether they are published or not. The documents may come from teaching and research institutions in France or abroad, or from public or private research centers.
L'archive ouverte pluridisciplinaire HAL, est destinée au dépôt et à la diffusion de documents scientifiques de niveau recherche, publiés ou non, émanant des établissements d'enseignement et de recherche français ou étrangers, des laboratoires publics ou privés. 


\section{First identification of a Cathaysian continental}

2 fragment beneath the Gagua Ridge, Philippine Sea,

3 and its tectonic implications

4

5 Shengping Qian ${ }^{1 * *}$, Xiaozhi Zhang ${ }^{1 \#}$, Jonny $\mathbf{W u}^{2}$, Serge Lallemand ${ }^{3}$, Alexander R.

6 L. Nichols ${ }^{4}$, Chiyue Huang ${ }^{1,5}$, Daniel P. Miggins ${ }^{6}$, Huaiyang Zhou ${ }^{1^{*}}$

7

$8{ }^{1}$ State Key Laboratory of Marine Geology, Tongji University, Shanghai 200092,

9 China

$10{ }^{2}$ Department of Earth \& Atmospheric Sciences, University of Houston, Houston,

11 Texas 77204, USA

$12{ }^{3}$ Géosciences Montpellier, CNRS, Montpellier University, 34095 Montpellier cédex 5,

13 France

$14{ }^{4}$ School of Earth and Environment, University of Canterbury, Christchurch 8140, New

15 Zealand

$16{ }^{5}$ Department of Earth Sciences, National Cheng Kung University, 701 Tainan, Taiwan

$17{ }^{6}$ College of Earth, Ocean and Atmospheric Sciences, Oregon State University, 18 Corvallis, OR 97331, USA

20 * Corresponding author: shengpingqian@tongji.edu.cn, zhouhy@tongji.edu.cn 
${ }^{*}$ Co-first author

\section{ABSTRACT}

25 The tectonic history of the Philippine Sea Plate is essential to understand the 26 tectonic evolution of Southeast Asia, but it is still unclear and controversial. Here, we 27 present the first geochemical data of lavas from the Gagua Ridge (GR) within the 28 Philippine Sea. The GR lavas exhibit geochemical signatures typical of 29 subduction-related arc magmatism. Plagioclase Ar-Ar ages of 123-124 Ma, as well as 30 subduction-related geochemical signatures, support the formation of GR lavas in the

31 vicinity of an arc during the Early Cretaceous induced by subduction of the oceanic 32 plate along East Asia. The ages of trapped zircon xenocrysts within the GR lavas cluster 33 at $250 \mathrm{Ma}, 0.75 \mathrm{Ga}$ and $2.45 \mathrm{Ga}$, and match well the ages of zircons recovered from the 34 Cathaysian block, South China. Our results imply that the GR basement is partially 35 comprised of continental material that rifted away from the Eurasian margin during 36 opening and spreading of the Huatung Basin (HB). The depleted mantle wedge-derived magmas evolved and picked up the continental zircons during ascent. The youngest

38 zircon ages and the GR lava Ar-Ar ages ( 123-124 Ma) presented in this study newly

39 constrain an Early Cretaceous age for the HB. Our study provides further evidence that 40 the HB is a remnant of a Mesozoic-aged ocean basin that dispersed from South China

41 during the Cretaceous. Transport of continental slivers by growth and closure of 
42 marginal seas along the East Asia margin may have been more prevalent than 43 previously recognized.

44

45

INTRODUCTION

46 The Philippine Sea Plate (PSP) is composed of a mosaic of marginal basins, and

47 is almost completely bounded by subduction zones that involve the

48 Eurasian/Sundaland plates to the west, the Pacific Plate to the east, and the

49 Indo-Australian Plate to the south (e.g. Hall, 2002). Tectonic studies of the PSP have a

50 profound influence on the origin of marginal seas, and plate tectonic reconstructions

51 for vast areas of Southeast (SE) China, SE Asia and western Pacific regions since the

52 Cretaceous (Hilde and Lee, 1984; Hall, 2002; Sibuet et al., 2002; Hsu and

53 Deffontaines, 2009; Zahirovic et al., 2014; Lallemand, 2016; Wu et al., 2016; Huang

54 et al., 2019). Although some portions of the PSP are better-studied and show oceanic

55 basins and ocean island arc lithosphere of Early Cretaceous to recent ages

56 (Deschamps and Lallemand, 2002; Taylor and Goodliffe, 2004; Hickey-Vargas et al.,

57 2008; Tani et al., 2011), other areas are completely undrilled and remain enigmatic.

58 One such region is the Huatung Basin (HB) and the Gagua Ridge (GR) along the

59 northwestern PSP (Fig. 1), the focus of this study.

60 The northwestern PSP is composed of two ocean basins: the larger and 61 better-studied West Philippine Basin (WPB), and the undrilled, smaller HB (Fig. 1).

62 The GR is a bathymetric high between the HB and WPB, occupying a unique position 
63 (Fig. 1). Existing interpretations regarding the origin of the GR are diverse, including

64 an uplifted sliver of oceanic crust (Mrozowski et al., 1982), a former intraoceanic

65 fracture zone (Deschamps et al., 1998), WPB-HB plate boundary (Deschamps et al.,

66 2000; Sibuet et al., 2002), or a relict subduction zone (i.e. westward subduction of the

67 WPB beneath the HB along the GR) (Deschamps and Lallemand, 2002; Eakin et al.,

68 2015). Each scenario has wide-ranging implications for HB-WPB interactions and SE

69 Asian plate tectonic evolution and is explored in this study.

70 Here, we present new Ar-Ar geochronology and geochemistry for GR lavas:

71 major and trace element, and $\mathrm{Sr}-\mathrm{Nd}-\mathrm{Hf}-\mathrm{Pb}$ isotope data for the whole rocks; and

$72 \mathrm{U}-\mathrm{Pb}-\mathrm{Hf}$ isotopic and trace element data for zircons from the lavas. Combined with

73 the regional tectonic constraints, our study provides new insights into the nature,

74 origin and dispersal of the GR that elucidate the tectonic evolution of SE Asia.

\section{GEOLOGICAL SETTING AND SAMPLES}

77 The HB is a small ocean basin that has an enigmatic tectonic history. Deschamps

78 and Lallemand (2002) proposed that the HB was near-equatorial in the early Cenozoic

79 and then docked against the adjacent WPB along the GR around $\sim 35 \mathrm{Ma}$, while Hall

80 (2012) considers the HB to have been near $\sim 20^{\circ} \mathrm{N}$ latitudes for most of its history. If

81 the HB and Luzon were already juxtaposed by the Eocene, Luzon paleomagnetism

82 similarly places the HB near the equator or even at low latitudes within the southern

83 hemisphere during the Eocene (Queano et al., 2007). Wu et al. (2016) follows Queano 
84

et al. (2007) and reconstructs Luzon-HB to be within the now-vanished marginal 'East Asia Sea'.

The GR is adjacent to an unusual subduction flipping system (e.g. the PSP subducting northwestward along the Ryukyu Trench, and the South China Sea (SCS) subducting eastward along the Manila Trench) (Angelier, 1986; Sibuet et al., 2002)

(Fig. 1). The geophysical data indicates crustal thickening on the order of $\sim 12-18 \mathrm{~km}$ beneath the GR (Eakin et al., 2015). Besides, the northernmost segment of this linear GR subducts beneath the Ryukyu trench (Deschamps et al., 1998; Dominguez et al., 1998).

Lavas were collected from the GR by ROV Haixing6000 (Fig. 1). Four sites around the highest peak of the ridge were investigated but only those located at the top provided relatively fresh volcanic rocks (Fig. DR1 and DR2A). The lavas are massive and porphyritic, containing clinopyroxene, plagioclase and orthopyroxene phenocrysts

(Fig. DR2C and D). Some plagioclases have resorption textures, leaving incomplete and crooked rims (Fig. DR2D). plots are provided in the supplementary material.

\section{RESULTS}

The zircons from the GR lavas show an age spectrum mainly ranging from Cretaceous to Archean, with three prominent population peaks at $250 \mathrm{Ma}(\mathrm{n}=13), 750$ 
$105 \mathrm{Ma}(\mathrm{n}=24)$, and $2450 \mathrm{Ma}(\mathrm{n}=14)$ (Fig. 2B). The zircons display a wide range of $\varepsilon_{\mathrm{Hf}}(\mathrm{t})$

106 values, from -31.0 to 23.8 (Fig. 2A), corresponding to highly variable crustal model

107 ages $\left(T_{D M}{ }^{C}\right)$ between ca. $382 \mathrm{Ma}$ and 3015 Ma (Table DR4), consistent with a

108 heterogenous source. Plagioclases in the GR lavas yielded weighted Ar-Ar mean ages

109 of $123.99 \pm 0.24 \mathrm{Ma}$ and $124.06 \pm 0.27 \mathrm{Ma}$ (Fig. 2E, F).

110 Generally, the GR lavas show a limited variation in major elements (e.g., $\mathrm{SiO}_{2}$ :

$11154.38-56.21 \mathrm{wt} \%$, total alkalis: $4.32-5.87 \mathrm{wt} . \%)$, and are mainly basaltic andesites

112 (Fig. 3A). They are characterized by the enrichment of large ion lithophile elements

113 (LILEs, e.g. $\mathrm{Ba}, \mathrm{U}, \mathrm{K}$ and $\mathrm{Pb}$ ), resembling the signature of subduction-related rocks

114 from circum-Pacific arcs (Fig. 3B). They all display depleted mantle-type isotopic

115 signatures, with low ${ }^{87} \mathrm{Sr} /{ }^{86} \mathrm{Sr}(0.703297-0.703574)$, and high ${ }^{143} \mathrm{Nd} /{ }^{144} \mathrm{Nd}(0.512972-$

116 0.513067) and ${ }^{176} \mathrm{Hf} /{ }^{177} \mathrm{Hf}(0.283112-0.283157)$ (Fig. 3F, G, H). The GR lavas show a

117 limited range of $\mathrm{Pb}$ isotope compositions $\left({ }^{206} \mathrm{~Pb} /{ }^{204} \mathrm{~Pb}=18.279-18.330,{ }^{207} \mathrm{~Pb} /{ }^{204} \mathrm{~Pb}=\right.$

118 15.476-15.493, and $\left.{ }^{208} \mathrm{~Pb} /{ }^{204} \mathrm{~Pb}=37.961-38.038\right)$ (Fig. 3E and Table DR1).

119

120

\section{CONTINENTAL FRAGMENT BENEATH THE GR}

$121 \mathrm{U}-\mathrm{Pb}$ ages of zircons in the GR lavas range widely from 123 to $3035 \mathrm{Ma}$ (Fig.

122 2A, B), which suggests that zircon grains are likely xenocrystic. The GR zircons have

123 high $\mathrm{U}$, Th and $\mathrm{Y}$ contents and $\mathrm{U} / \mathrm{Yb}$ values that markedly differ from those of

124 recycled oceanic crust, mantle peridotite and kimberlite, but resemble those of

125 continental crust (Fig. 2C, D). The U-Pb ages and Hf isotope systematics of the GR 
126 127 South China (Yu et al., 2010; Li et al., 2014). The Mesozoic age peak (250 Ma) of the

zircons (Fig. 2A, B) broadly match those of zircon records from the Cathaysian block, GR zircons can possibly be related to widespread contemporaneous magmatic rocks 129 in South China, while zircon age peaks $(\sim 0.75 \mathrm{Ga}$ and $\sim 2.45 \mathrm{Ga})$ are largely consistent with those for zircons from Cathaysia crust, South China (Fig. 2B). Thus, the GR zircons most likely originated from Cathaysian Block.

The GR zircons are likely inherited from crust-derived material within mantle sources. It is known that crust-derived materials only contain small amounts of accessory zircon. If our zircon xenocrysts are derived from recycled continental crust in the mantle source, the erupted lavas would have continental signatures, e.g., enriched Sr-Nd isotope, due to significantly higher trace element contents of recycled continental crust relative to mantle. However, these features are absent in the GR lavas (e.g. the depleted mantle-like $\mathrm{Sr}-\mathrm{Nd}$ isotopic compositions) (Fig. 3F). Furthermore, inherited zircons with multiple episodes of recycling and/or longdistance transport are typically well rounded or ellipsoidal with pitted surfaces. In contrast, most of the inherited zircons in the GR lavas are euhedral to subhedral (Fig.

DR3), suggesting no long-distance transport. All the above features argue against the GR zircons being from subducting sediment involving long transport distances or from crust with multiple episodes of recycling.

Alternatively, the zircons in the GR lavas could have been entrained from the Cathaysian crust during magma ascent and/or within the magma chamber. This 
147 implies the existence of continental crust beneath the GR. Compared to older 148 continental crust, the GR lavas have remarkably depleted Sr-Nd isotope compositions

149 (Fig. 3F), which suggests that juvenile parent magmas assimilated a small amount of 150 older material to incorporate zircon grains but not enough to dramatically affect 151 isotopic systematics.

152

\section{PETROGENESIS}

154 As shown in a multi-element spider diagram (Fig. 3B), enrichments in

155 fluid-mobile elements (e.g., U, K, Pb, Sr and $\mathrm{Ba}$ ) of the GR lavas are typical of 156 subduction-related magmatism. The relatively low $\mathrm{Ti} / \mathrm{V}$, as well as high $\mathrm{Ba} / \mathrm{Yb}$, of the 157 GR lavas represent subduction-related signatures (Fig. 3C, D). Unlike mature arc 158 systems (e.g. Luzon and Ryukyu Arc), the isotopic compositions of the GR lavas plot 159 far away from the domain of global subducting sediment (GLOSS, Plank and Langmuir, 160 1998) (Fig. 3E, F, G). In particular, the GR lavas are distributed along the mantle array 161 on the plot of ${ }^{143} \mathrm{Nd} /{ }^{144} \mathrm{Nd}$ versus ${ }^{176} \mathrm{Hf} /{ }^{177} \mathrm{Hf}$ (Fig. 3H), suggesting fairly minor 162 contribution from subducting sediment to the mantle source (Plank and Langmuir, 163 1998; Hickey-Vargas et al., 2008). Additionally, the GR lavas have a typical 164 subducted slab-derived 'fluid' signature with low $\mathrm{Nd} / \mathrm{Pb}(<4.3$ relative to $\sim 20$ in 165 mid-ocean ridge basalts) (Fig. 3E). In the case of the GR lavas, the elevations of $166 \mathrm{Sr} / \mathrm{Th}$ and $\mathrm{Ba} / \mathrm{La}$, coupled with the narrow variations of $\mathrm{Th} / \mathrm{Ce}$ and $\mathrm{Th} / \mathrm{Yb}($ Fig. DR4) 167 also underline a significant contribution of slab-derived fluids to the mantle source. 
168 Consequently, we postulate that the GR lavas are derived from depleted mantle that

169 had been metasomatized by subducted slab-related materials. Following the approach

170 of Ishizuka et al. (2003), a simple simulation shows that the mantle source of the GR

171 lavas was likely to be metasomatized by $\sim 4 \%$ fluid derived from altered oceanic crust

172 (AOC) and subducted sediment in a mixing ratio of 50:50 to 90:10 (Fig. 3F and G).

173 The GR lavas show subduction-related arc geochemical signatures, suggesting a

174 past subduction event. The GR lavas formed by 124 Ma (Fig. 2E, F), which is also

175 consistent with the minimum age $(123 \pm 1.7 \mathrm{Ma})$ of zircon in the GR lavas within

176 error (Table DR2). Thus, it is most likely that the GR lavas are derived from a mantle

177 source region metasomatised by slab-derived fluids along South China during the

178 Cretaceous, which was an active margin (e.g. Hall, 2012). In terms of geochemical

179 compositions, the HB lavas have compositions similar to lavas formed in back-arc

180 basin and spreading centers (e.g., $\mathrm{Nb}$, Ta and Ti enrichments, relatively high $\mathrm{Nd} / \mathrm{Pb}$

181 and $\mathrm{Ti} / \mathrm{V}$, and low $\mathrm{Ba} / \mathrm{Yb}$, Fig. 3), while the GR lavas are more influenced by

182 subducted components (the arc or close to rear-arc position).

183

184 IMPLICATIONS FOR SE ASIA TECTONIC EVOLUTION

185 Published geophysical and geochemical data, sedimentation rates, and 186 geomagnetic modeling, show that the $\mathrm{HB}$ is likely a trapped remnant of

187 Cretaceous-aged oceanic basin (Deschamps et al., 2000; Hickey-Vargas et al., 2008;

188 Eakin et al., 2015; Huang et al., 2019; Hsieh et al., 2020). However, other studies 
favor a younger age for the HB based on seafloor magnetics and seismology,

190 including Eocene (Hilde and Lee, 1984), Eocene to Miocene (Sibuet et al., 2002),

191 Oligo-Miocene (Kuo et al., 2009), or mid-late Eocene (Doo et al., 2014). Our study

192 affirms a Cretaceous age for the HB based on our GR lava eruption ages and the

193 youngest zircon ages of $\sim 123-124 \mathrm{Ma}$ (Fig. 2 and Table DR2).

194 Our identification of a Cathaysian continental fragment in the Philippine Sea

195 suggests that HB formation could be related to rifting of the Cathaysian Block during

196 the Cretaceous, when SE China transitioned from an active subducting margin to

197 extension (Xu et al., 2014; Zahirovic et al., 2016). It is also possible that the HB

198 formed during the Early Cretaceous from 131 to 119 Ma (Deschamps et al., 2000);

199 both cases imply rifting of a Cathaysian continental fragment during the Cretaceous.

200 Combining published plate models with our results, the HB could be either

201 far-traveled or remained relatively close to Eurasia during its history (Fig. 4). In the

202 far-traveled scenario, the HB was located near South China in the Early Cretaceous,

203 drifted $\sim 2000 \mathrm{~km}$ southwards to equatorial latitudes by the Eocene, and then followed

204 the PSP and Luzon $\sim 2000 \mathrm{~km}$ northwards after $50 \mathrm{Ma}$ to its present position (Fig. 4).

205 Southward drift of the HB could be accommodated by opening of a backarc basin or

206 marginal sea near South China, including a large proto-SCS or other vanished

207 marginal seas (Deschamps and Lallemand, 2002; Wu et al., 2016; Zahirovic et al.,

208 2016). Alternatively, a 'short transport' scenario is possible where the HB is a relict

209 proto-SCS fragment that remained relatively close to South China, moved $\sim 500 \mathrm{~km}$ 
210 southwards during the SCS opening, was captured by the PSP and then moved 500

211 km northwards (Fig. 4) (Hall, 2012). This scenario requires the HB to be tectonically

212 transported a shorter distance and seems more favorable (Fig. 4), and is still

213 compatible within specific constraints used by far-traveled plate models (Deschamps

214 and Lallemand, 2002; Wu et al., 2016).

215 Another sliver of Cathaysian-affinity continent has been found within the Luzon

216 Arc basement that apparently drifted southwards during the SCS opening, was

217 accreted and then moved northwards with the PSP during the mid- to late Cenozoic

218 (Shao et al., 2015). Taken together, we newly present the undrilled HB as a narrow

219 (up to $150 \mathrm{~km}$ wide) sliver of oceanic crust, bounded on both sides by continental

220 fragments of Cathaysian-affinity (Fig. 4). Accretion of 'ribbon continents' is

221 fundamental in orogenesis and continental growth over time and space (Cawood et al.,

222 2009). Our results now show that the transport of continental slivers by growth and

223 closure of marginal seas along the East Asia margin (Fig. 4) may be more prevalent

224 than previously recognized.

225

226 ACKNOWLEDGMENTS

227 This study was supported by the National Natural Science Foundation (NSF) of China

228 (41902044 and 91428207) and the Chinese National Key Basic Research Program

229 (2012CB417300). Jonny Wu was supported by US NSF grant EAR-1848327. We thank

230 editor Prof. Gerald Dickens, reviewer Sabin Zahirovic, and two anonymous reviewers 
231 for their constructive and helpful reviews. Stéphane Dominguez is thanked for 232 providing the bathymetric compilation. Shenyang Institute of automation and Zhiguo 233 Qiao are thanked for helping collect the sample. We thank Le Zhang for assistance in 234 the sample analysis.

235

236 REFERENCES CITED

237 Angelier, J., 1986, Geodunamics of the Eurasia-Philippine Sea plate boundary: 238 preface: Tectonophysics, v. 125, no. 1, p. IX-X, 239 doi.org/10.1016/0040-1951(86)90003-X.

240 Cawood, P. A., Kröner, A., Collins, W. J., Kusky, T. M., Mooney, W. D., and Windley, 241 B. F., 2009, Accretionary orogens through Earth history: Geological Society, 242 London, Special Publications, v. 318, no. 1, p. 1-36, doi:10.1144/sp318.1.

243 Deschamps, A., and Lallemand, S., 2002, The West Philippine Basin: An Eocene to 244 early Oligocene back arc basin opened between two opposed subduction zones: 245 Journal of Geophysical Research, v. 107, doi:10.1029/2001JB001706.

246 Deschamps, A. E., Lallemand, S. E., and Collot, J.-Y., 1998, A detailed study of the 247 Gagua Ridge: A fracture zone uplifted during a plate reorganisation in the 248 Mid-Eocene: Marine Geophysical Researches, v. 20, no. 5, p. 403-423, 249 doi:10.1023/A:1004650323183.

250 Deschamps, A., Monié, P., Lallemand, S., Hsu, S. K., and Yeh, K. Y., 2000, Evidence 251 for Early Cretaceous oceanic crust trapped in the Philippine Sea Plate: Earth 
252

253

254

255

256

257

258

259

260

261

262

263

264

265

266

267

268

269

270

271

272 and Planetary Science Letters, v. 179, no. 3, p. 503-516, doi:https://doi.org/10.1016/S0012-821X(00)00136-9.

Dominguez, S., Lallemand, S., Malavieille, J., and Schnürle, P., 1998, Oblique subduction of the Gagua Ridge beneath the Ryukyu accretionary wedge system: Insights from marine observations and sandbox experiments: Marine Geophysical Researches, v. 20, p. 383-402, doi:10.1023/A:1004614506345.

Doo, W., Hsu, S.-K., Yeh, Y.-C., Tsai, C.-H., and Chang, C.-M., 2014, Age and tectonic evolution of the northwest corner of the West Philippine Basin: Marine Geophysical Research, v. 36, doi:10.1007/s11001-014-9234-8.

Eakin, D. H., McIntosh, K. D., Van Avendonk, H. J. A., and Lavier, L., 2015, New geophysical constraints on a failed subduction initiation: The structure and potential evolution of the Gagua Ridge and Huatung Basin: Geochemistry, Geophysics, Geosystems, v. 16, no. 2, p. 380-400, doi:10.1002/2014gc005548.

Grimes, C. B., John, B., Kelemen, P., Mazdab, F. K., Wooden, J., Cheadle, M. J., Hanghoj, K., and Schwartz, J., 2007, Trace element chemistry of zircons from oceanic crust: A method for distinguishing detrital zircon provenance: Geology, v. 35, doi:10.1130/G23603A.1.

Hall, R., 2002, Cenozoic geological and plate tectonic evolution of SE Asia and the SW Pacific: computer-based reconstructions, model and animations: Journal of Asian Earth Sciences, v. 20, no. 4, p. 353-431, doi:https://doi.org/10.1016/S1367-9120(01)00069-4. 
273 Hall, R, 2012, Late Jurassic-Cenozoic reconstructions of the Indonesian region and 274 the Indian Ocean: Tectonophysics, v. 570-571, p. 1-41, 275 doi:https://doi.org/10.1016/j.tecto.2012.04.021.

276 Hickey-Vargas, R., Bizimis, M., and Deschamps, A., 2008, Onset of the Indian Ocean 277 isotopic signature in the Philippine Sea Plate: $\mathrm{Hf}$ and $\mathrm{Pb}$ isotope evidence from 278 Early Cretaceous terranes: Earth and Planetary Science Letters, v. 268, no. 3, p. 279 255-267, doi:https://doi.org/10.1016/j.epsl.2008.01.003.

280 Hilde, T. W. C., and Lee, C.-S., 1984, Origin and evolution of the West Philippine 281 Basin: A new interpretation: Tectonophysics, v. 102, no. 1, p. 85-104, doi:https://doi.org/10.1016/0040-1951(84)90009-X.

283 Hsieh, Y.-H., Liu, C.-S., Suppe, J., Byrne, T. B., and Lallemand, S., 2020, The Chimei 284 Submarine Canyon and Fan: A Record of Taiwan Arc-Continent Collision on 285 286 the Rapidly Deforming Overriding Plate: Tectonics, v. 39, no. 11, p. e2020TC006148.

Hsu, S.-K., and Deffontaines, B., 2009, An introduction to geodynamics and active tectonics in East Asia: Tectonophysics, v. 466, p. 135-139, doi:10.1016/j.tecto.2007.11.013.

290 Huang, C.-Y., Wang, P., Yu, M., You, C.-F., Liu, C.-S., Zhao, X., Shao, L., Zhong, G., 291 and Yumul, G. P., Jr, 2019, Potential role of strike-slip faults in opening up the 292 South China Sea: National Science Review, v. 6, no. 5, p. 891-901, 293 doi:10.1093/nsr/nwz119. 
294 Ishizuka, O., Taylor, R. N., Milton, J. A., and Nesbitt, R. W., 2003, Fluid-mantle 295 interaction in an intra-oceanic arc: constraints from high-precision $\mathrm{Pb}$ isotopes: 296 Earth and Planetary Science Letters, v. 211, no. 3, p. 221-236, 297 doi:https://doi.org/10.1016/S0012-821X(03)00201-2.

298 Kuo, B.-Y., Chi, W.-C., Lin, C.-R., Chang, E. T.-Y., Collins, J., and Liu, C.-S., 2009, 299 Two-station measurement of Rayleigh-wave phase velocities for the Huatung 300 basin, the westernmost Philippine Sea, with OBS: implications for regional 301 tectonics: Geophysical Journal International, v. 179, no. 3, p. 1859-1869, 302 doi:10.1111/j.1365-246X.2009.04391.x.

303 Lallemand, S., 2016, Philippine Sea Plate inception, evolution, and consumption with 304 305 306 special emphasis on the early stages of Izu-Bonin-Mariana subduction: Progress in Earth and Planetary Science, v. 3, no. 1, p. 15, doi:10.1186/s40645-016-0085-6.

307 Li, X.-H., Li, Z.-X., and Li, W.-X., 2014, Detrital zircon U-Pb age and Hf isotope 308 constrains on the generation and reworking of Precambrian continental crust in 309 the Cathaysia Block, South China: A synthesis: Gondwana Research, v. 25, no. 310 3, p. 1202-1215, doi:https://doi.org/10.1016/j.gr.2014.01.003.

311 Mrozowski, C. L., Lewis, S. D., and Hayes, D. E., 1982, Complexities in the tectonic 312 evolution of the West Philippine Basin: Tectonophysics, v. 82, no. 1, p. 1-24, 313 doi:https://doi.org/10.1016/0040-1951(82)90085-3.

314 Plank, T., and Langmuir, C. H., 1998, The chemical composition of subducting 
sediment and its consequences for the crust and mantle: Chemical Geology, v. 145, no. 3-4, p. 325-394, doi:Doi 10.1016/S0009-2541(97)00150-2.

Queano, K. L., Ali, J. R., Milsom, J., Aitchison, J. C., and Pubellier, M., 2007, North Luzon and the Philippine Sea Plate motion model: Insights following paleomagnetic, structural, and age-dating investigations: Journal of Geophysical Research: Solid Earth, v. 112, no. B5, doi:10.1029/2006jb004506.

Shao, W.-Y., Chung, S.-L., Chen, W.-S., Lee, H.-Y., and Xie, L.-W., 2015, Old continental zircons from a young oceanic arc, eastern Taiwan: Implications for Luzon subduction initiation and Asian accretionary orogeny: Geology, v. 43, no. 6, p. 479-482, doi:10.1130/G36499.1.

Shervais, J. W., 1982, Ti-V plots and the petrogenesis of modern and ophiolitic lavas: Earth and Planetary Science Letters, v. 59, no. 1, p. 101-118, doi:https://doi.org/10.1016/0012-821X(82)90120-0.

Sibuet, J.-C., Hsu, S.-K., Le Pichon, X., Le Formal, J.-P., Reed, D., Moore, G., and Liu, C.-S., 2002, East Asia plate tectonics since 15 Ma: constraints from the Taiwan region: Tectonophysics, v. 344, no. 1, p. 103-134, doi:https://doi.org/10.1016/S0040-1951(01)00202-5.

Tani, K., Dunkley, D. J., and Ohara, Y., 2011, Termination of backarc spreading: Zircon dating of a giant oceanic core complex: Geology, v. 39, no. 1, p. 47-50, doi:10.1130/G31322.1. 
336 Taylor, B., and Goodliffe, A. M., 2004, The West Philippine Basin and the initiation of 337 subduction, revisited: Geophysical Research Letters, v. 31, no. 12, 338 doi:10.1029/2004g1020136.

339 Wu, J., Suppe, J., Lu, R., and Kanda, R., 2016, Philippine Sea and East Asian plate 340 tectonics since $52 \mathrm{Ma}$ constrained by new subducted slab reconstruction 341 methods: Journal of Geophysical Research: Solid Earth, v. 121, no. 6, p. 342 4670-4741, doi:10.1002/2016jb012923.

343 Xu, J., Ben-Avraham, Z., Kelty, T., and Yu, H.-S., 2014, Origin of marginal basins of 344 the NW Pacific and their plate tectonic reconstructions: Earth-Science 345 346 347 348 349 350 $\begin{array}{llll}\text { Reviews, } & \text { v. } & 130, & \text { p. }\end{array}$ doi:https://doi.org/10.1016/j.earscirev.2013.10.002.

Yu, J.-H., O’Reilly, S. Y., Wang, L., Griffin, W. L., Zhou, M.-F., Zhang, M., and Shu, L., 2010, Components and episodic growth of Precambrian crust in the Cathaysia Block, South China: Evidence from $\mathrm{U}-\mathrm{Pb}$ ages and $\mathrm{Hf}$ isotopes of zircons in Neoproterozoic sediments: Precambrian Research, v. 181, no. 1, p.

352 Zahirovic, S., Seton, M., and Müller, R. D., 2014, The Cretaceous and Cenozoic 353 tectonic evolution of Southeast Asia: Solid Earth, v. 5, no. 1, p. 227-273, 354 doi:10.5194/se-5-227-2014.

355 Zahirovic, S., Matthews, K. J., Flament, N., Müller, R. D., Hill, K. C., Seton, M., and 356 Gurnis, M., 2016, Tectonic evolution and deep mantle structure of the eastern 
Tethys since the latest Jurassic: Earth-Science Reviews, v. 162, p. 293-337, doi:https://doi.org/10.1016/j.earscirev.2016.09.005.

\section{FIGURE CAPTIONS}

Fig. 1. Geological map of the Gagua Ridge (GR) and adjacent regions. Red star, sampling location of GR lavas; Black star, Taiwan Cathaysian continental fragment of Shao et al. (2015).

Fig. 2. (A) $\varepsilon_{\mathrm{Hf}}(\mathrm{t})$ versus $\mathrm{U}-\mathrm{Pb}$ age, (B) U-Pb age histogram, (C) Th versus $\mathrm{U}$, (D) $\mathrm{U} / \mathrm{Yb}$ versus $\mathrm{Y}$ of zircons sampled from the Gagua Ridge (GR) lavas. For comparison, the zircons from continental and oceanic crust, and mantle peridotite and kimberlite (Grimes et al., 2007 and references therein), eastern Taiwan lavas (Shao et al., 2015) and Cathaysia Block detrital zircons (Yu et al., 2010) are plotted. (E-F) ${ }^{40} \mathrm{Ar} /{ }^{39} \mathrm{Ar}$ age spectrum for plagioclase from the GR lavas.

Fig. 3. (A) Variation of total alkali $\left(\mathrm{Na}_{2} \mathrm{O}+\mathrm{K}_{2} \mathrm{O}\right)$ versus $\mathrm{SiO}_{2}$, (B) Primitive mantle-normalized trace element pattern, (C) Ti-V discrimination diagram (Shervais, 1982), (D) $\mathrm{Ba} / \mathrm{Yb}$ versus $\mathrm{Nb} / \mathrm{Yb}$, (E) ${ }^{206} \mathrm{~Pb} /{ }^{204} \mathrm{~Pb}$ versus $\mathrm{Nd} / \mathrm{Pb}$ and (F-H) Isotopic compositions of the Gagua Ridge (GR) lavas. The numbers adjacent to lines indicate the $\%$ of slab-derived fluid added to the source mantle (See data sources and isotope modeling details in Table DR5). 
379 Fig. 4. Present-day Southeast Asia map showing possible tectonic journey of the 380 Cathaysian-affinity continental crustal sliver beneath the Gagua Ridge (GR) found in 381 this study (red star). The continental sliver (red polygon) rifted from South China

382 during the Cretaceous and possibly followed one of two paths: far-traveled (purple path)

383 or short transport (orange path). Brown areas show present-day landmasses; green area 384 shows present-day Huatung Basin (HB).

385

386 Supplemental Material. Methods, and supplemental figures and Tables. Please visit $387 \mathrm{XX}$ to access the supplemental material. 


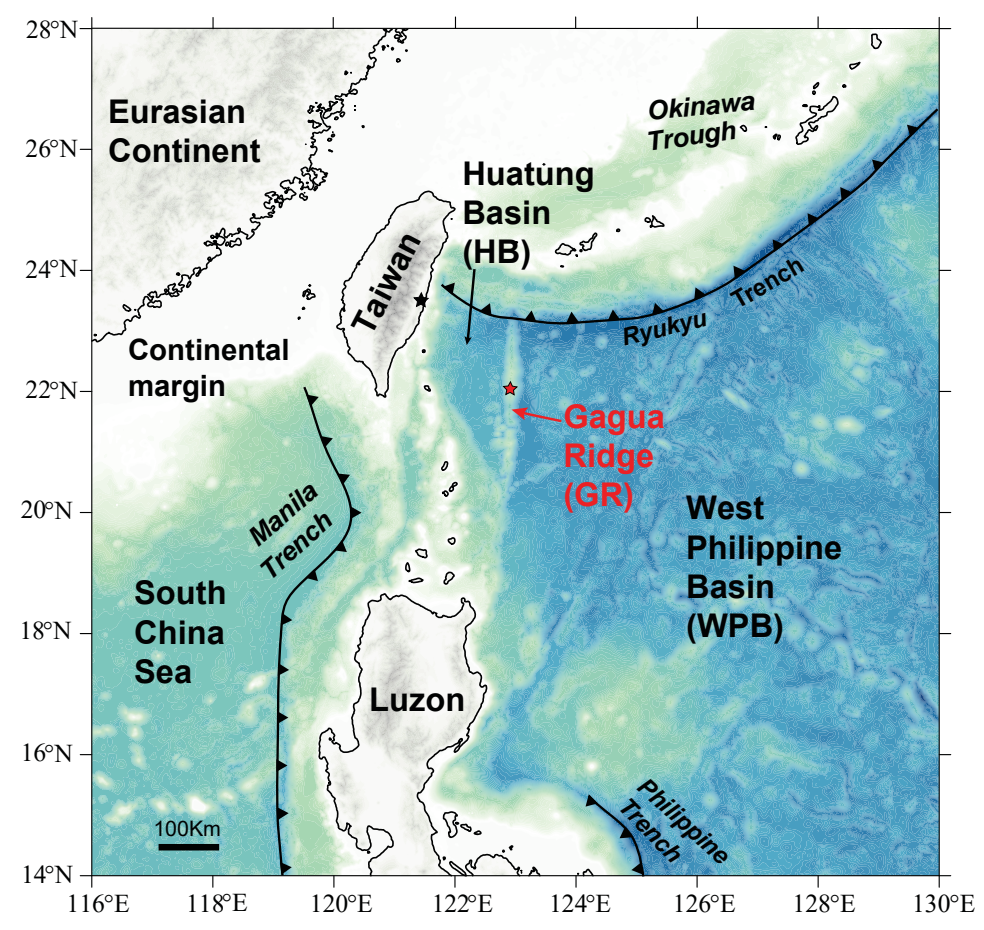



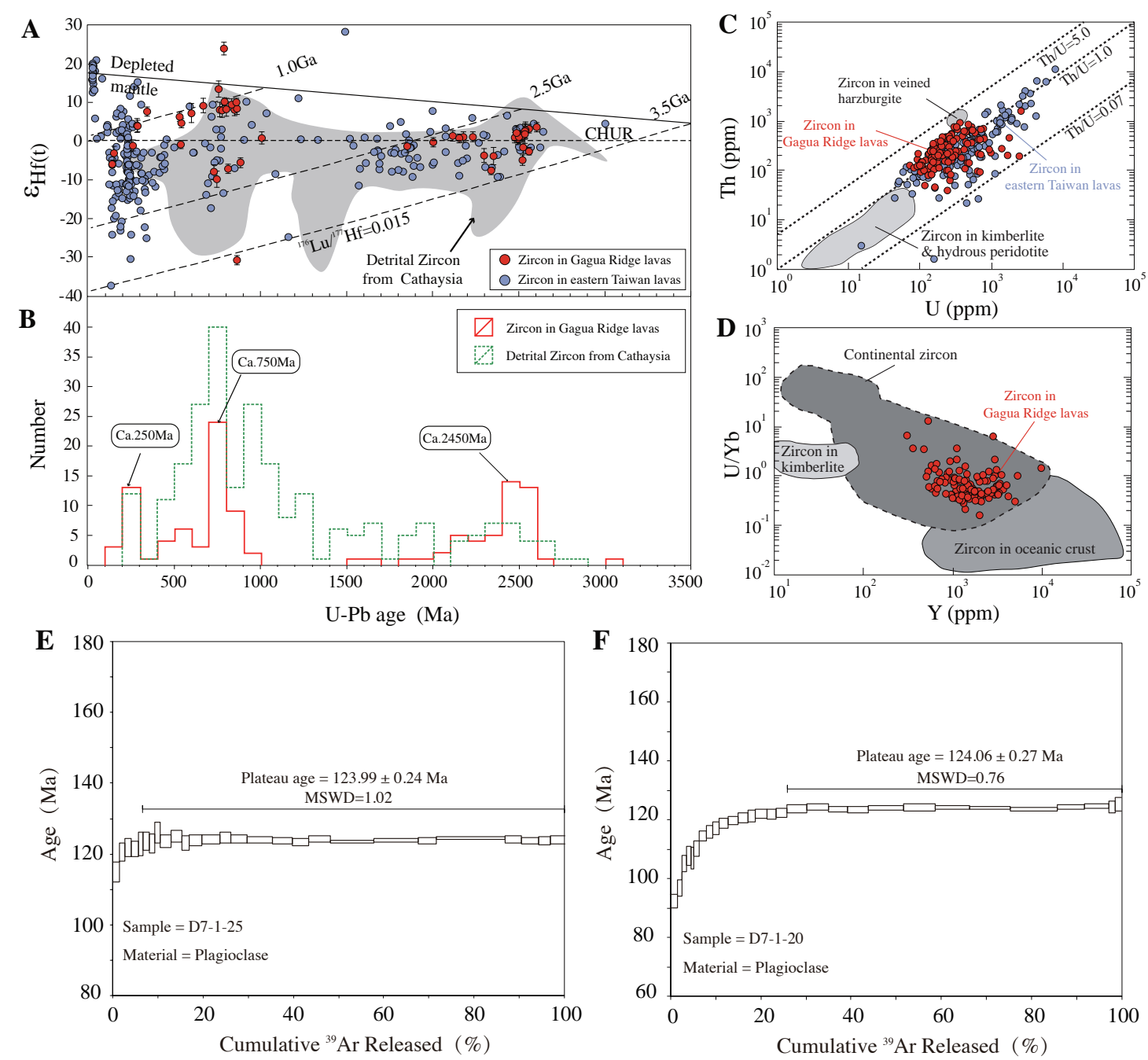
Figure 3
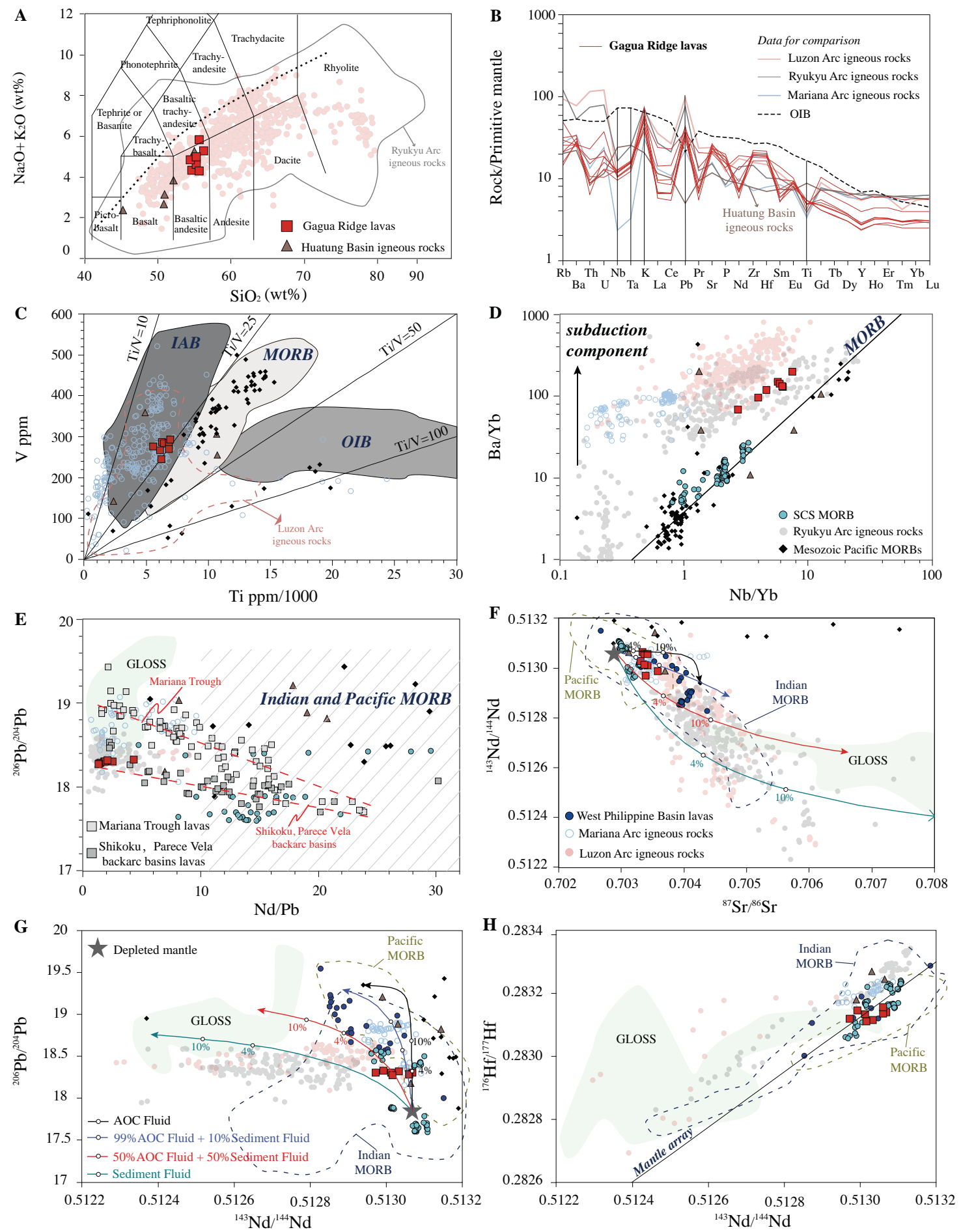


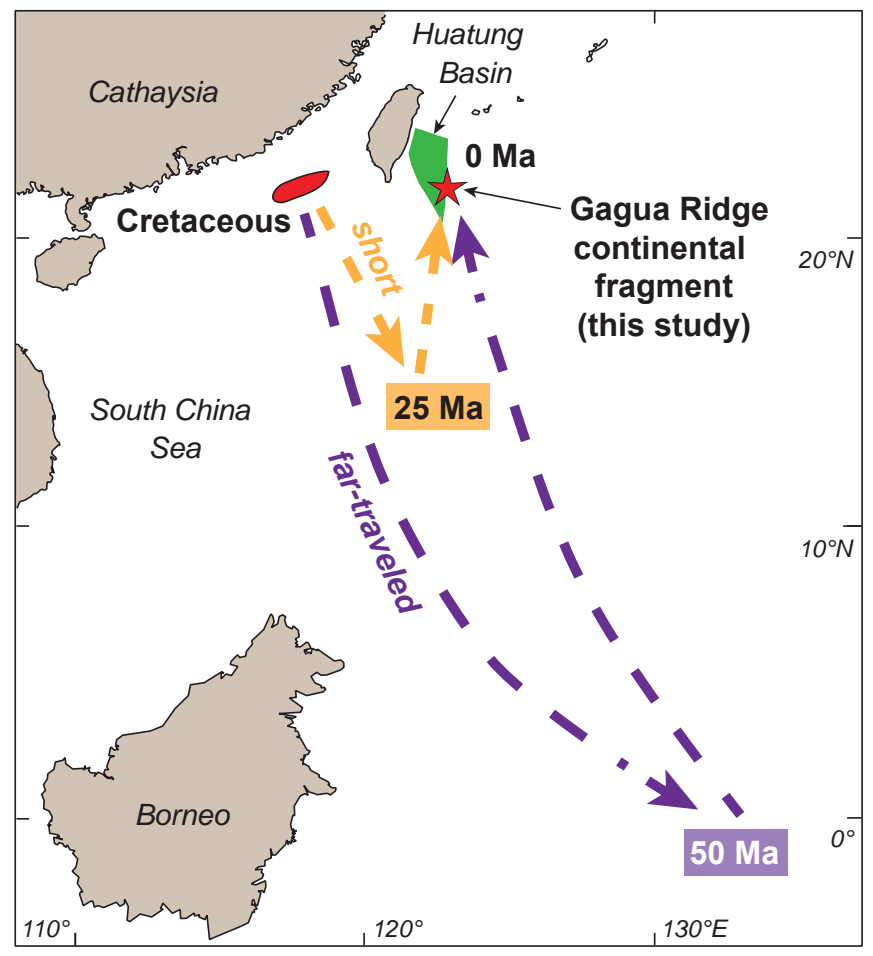

